\title{
Cognitive Engagement and Motoric Involvement in Learning: An Experiment on the Effect of Interaction Story Game on English Listening Comprehension in EFL Context
}

\author{
Berlin Sibarani \\ Correspondence: Berlin Sibarani, Universitas Negeri Medan, Indonesia.
}

Received: Nov. 25, 2019

Accepted: Dec. 23, 2019

Online Published: Dec.r 23, 2019

doi:10.5430/elr.v8n4p38

URL: https://doi.org/10.5430/elr.v8n4p38

\begin{abstract}
This study was intended to find out the significant effect of cognitive engagement and motoric involvement in listening comprehension. Interaction Story Game (ISG) was applied in an experimental group, consisting of 30 students, to promote cognitive and motoric involvement in listening comprehension. While to the control group, conventional technique was applied. The result of the study showed that the experimental group achieved significantly better listening comprehension than the control group did. The empirical evidence verified that cognitive engagement and motoric involvement significantly affected listening comprehension achievement. It also proved that ISG could increase the students' cognitive engagement and motoric involvement. Deeper concentration on the instructor's instruction, high competitiveness among the players, complexity of the game challenge and high motivation to win the game were some aspects enabling the ISG to promote cognitive engagement. The players' activity to press the buttons and control the mouse of the ISG caused the students to get high motoric involvement.
\end{abstract}

Keywords: listening comprehension, interaction story game, cognitive engagement, and motoric involvement

\section{Introduction}

In the context of teaching English as a foreign language (EFL), the fact that the students have low proficiency has become a problem for a long time for the English teachers. The finding of the underlying factors is believed to be one way to initiate the solution. Souriyavongsa (2013) added more consequences of the underlying factor, such as having low background knowledge in English, lack of confidence in using the language and loose interest in learning the language. In addition, it was found that the teaching method used in the EFL teaching is not effective and therefore it is also considered as the cause of the students' poor proficiency. Oral proficiency, like listening and speaking ability, is lower than literacy ability, such as reading and writing and this may be due to the lack of language exposure.

Listening comprehension is a mental activity which requires someone not only to recognize words being heard, but also requires the listener to get the speakers' intention beyond its literal meaning. In relation to this, Underwood (1999) explains that the process of listening comprehension involves three stages. The first stage shows that sounds go into the brain memory to be recognized based on listener's background knowledge of the language. The second stage, the information is processed by short-term memory. Sometimes the words may be uttered too fast so a listener may fail to recognize and understand the speakers. The third stage, the listener draws meaning from the utterances and transfers the information to the long-term memory. Due to the complex process, one needs to get engaged cognitively to get concentrated on understanding the utterances they are listening to.

Most of the experts agree that listening comprehension is a complex process. Rost (2011) claims that listening has four main attributes, each of which cognitively interacts in processing texts, they are receptive, constructive, collaborative and transformative. The attributes cover the process of listening comprehension from the very basic one, in which meaning is perceived as the proposition of the utterances or their literal meaning up to the most complex one, in which the meaning is perceived as speakers' intention or pragmatics meaning. In such a complex process, interactive cognitive process takes place in a listener's mind. In the listener's mind, his knowledge of the language system, of the content, of the context, and of the speakers. Many researchers have proved that this theory is true. Sarandi (2010) found out that in order to be able to proceed an oral text well, a listener should know about the content knowledge relevant to the topic of the text he is listening to. The content knowledge that the listener know is called prior knowledge. How well the processing of the text happens depends on how deep and how well the prior knowledge is structured in the 
listener's mind. The two factors, namely how deep and how well the prior knowledge are structured in the listener's mind, enable the listener cognitively to interact with the clues of the text and such interactive cognitive process facilitates maximum comprehension of the text he is listening to. Research by Andringa (2012) confirmed that knowledge of linguistics, known also as formal schemata and knowledge of content, also called content schemata, as represented by the knowledge of vocabulary, semantics, and grammar is a significant determiner of listening comprehension of both native and non-native language speaker. The two types of knowledge are used maximally with good word monitoring, self-face, and working memory. The last three aspects are also found to be significant determiners of listening comprehension. The interaction between the two groups of determiners facilitates better listening comprehension of native and non - native speakers.

Listening comprehension is a part of learning which happens through oral channel. To go on or to abandon learning depends on how interest a learner in learning an object. Interest, then, may be considered as determinant factor of learning. Arnaldi (2014) showed that quality of brain activity, also called as cognitive activity in education terminology, the situation in which the brain activity (cognitive activity) takes place, and motoric function involved in the activity significantly determine the increase of learning interest. Since listening comprehension is considered as part of learning, then the increase of interest to listen to an oral language also depends on the three factors: brain activity or cognitive activity, the situation in which the cognitive activity happens, andmotoric function involvement. I

In foreign language classroom, video games can be an advantageous learning media that attracts students' attention. When they show interest in the learning environment, they will likely give more attention and perform better. This is proven through a study conducted by Vahdat \& Behbahani (2013) who found that video games when used in the classroom successfully attracted students' attention and helped them comprehend new vocabulary. Computer can also be an advantageous learning media. Isik (2010) found out the CALL (Computer Assisted Language Learning) significantly affected listening comprehension. Those students taught with CALL perform listening comprehension better and show better attitude towards learning English than those taught with conventional method. The positive attitude made the students feel good in learning. The improvement of listening comprehension and students' attitude was caused by immediate feedback provision. The immediate feedback also caused the students to be more cognitively and metacognitively active. Digital versatile disc (DVD) is facilitative to listening comprehension achievement. Hayati (2011) provided three types of treatment to the three groups of samples. The three groups were assigned to watch the same DVD with the title of Wild Weather. The first group watched the Wild Weather with English subtitle, the second group with Persian subtitle, and the third with no subtitle. The results of the study showed that the group provided with the English subtitle did much better in listening comprehension than the group with Persian subtitle, and the Persian subtitle group perform better than the group with no subtitle. This finding indicates that the Persian subtitle group does not need to work hard to understand the utterances in the movie because Persian is their native language. They did not engage cognitively very much in understanding the movie. They might sometimes pay attention to the utterances they heard and matched them with the Persian translation. Such simple cognitive engagement allowed them to comprehend the utterances and this might cause them to perform better than the group with no subtitle. The English subtitle group performed much better than the Persian subtitle group. The English subtitle group may have learned English and they may be better in reading than in listening. The movie with the English subtitle allows them to get more cognitively engaged because they can match the subtitle they hear and the English they learned. Loniza (2018) found out that the digital storytelling significantly affect listening comprehension because the digital storytelling was provided with images, video, audio narration and music which make it enjoyable. The student's enjoyment cause the students to get more engaged and motivated in listening to the storytelling and therefore their concentration to the audio narration became increased and consequently their listening comprehension is much better.Motoric involvement may be considered as a determinant factor of listening comprehension. Olstrom (2012) said that the extent to which one can comprehend an oral text is partly determined by one's ability to maintain one's engagement in processing oral texts. The degree of the motoric involvement can maintain one's engagement in listening comprehension.

Interest can also be a determinant factor for listening comprehension. Conard (2014) found out that listening comprehension increases when the content information conveyed in a video channel is interesting and the cognitive process of listening comprehension is not decreased with the interruptions. If the situational interest is high, it might motivate the activation of more cognitive process, particularly in working memory, which could allow the individual to better attend to content being learned in spite of interruptions together (Conard \& Robert, 2014).

Cognitive engagement is required during the process of listening comprehension. McLaughlin (2005:32) states that there are two types of cognitive engagement: procedural and substantive. Procedural engagement refers to students' commitment to adhere the rules and regulations in the classroom; while substantive engagement refers to students' prolonged mental concentration. Teachers or researchers may be able to observe the students' activity in terms of their 
cognitive engagement when they are assigned tasks that require mental effort.

Through the computer program, the interaction in the game can take various forms, such as instructions from a character to the game player and vice versa, explanation, description, narration and conversation. The video game contains many contents with various contexts, such as adventure, drama, etc. With such computer technology, a game player can choose to play the role of a character in the video game and identify himself perfectly as the character. The game players are supposed to understand verbal communication during the game and required to be emotionally and cognitively engaged to survive all contextual problems. they are to get engaged in motoric action as well in handling all tools for running the game.

Interaction Story Game (ISG) was assumed as the effective media in learning listening comprehension. This assumption is underlain on the experience that students get through while they are playing ISG. While playing ISG, the players likely try to be aware of what their opponent wants to do; thus, they need to set their strategy which occurs in their cognitive process, for the sake of winning the game. At the same time, the players must control their moves in using the keyboards in which this action refers to their psychomotor involvement. In addition, ISG enables the players to interact with the character they are playing with. The player listens to what the ISG suggests the players to do such as warning them that their opponents are around and so on. For this activity, the players need to have deep concentration or to stick with cognitive and psychomotor engagement in order to win the game as well as to comprehend what the speakers are saying during the game.

\section{Method}

This study was conducted with experimental research design in which the experimental group was treated with ISG, while the control group was taught with the conventional teaching method. To the two groups an objective test of listening comprehension was administered. The pre-test, that is the listening comprehension test administered before the treatment was used to confirm if the two groups were homogeneous or equal in terms of listening comprehension ability. The post test, that is the listening comprehension test administered after the treatment was completed, was used to find out if the ISG significantly affected the students' listening comprehension. The scores of the post-test were compared by using statistical formula of $t$ test.

\section{Results}

The data analysis revealed that the highest score of the experimental group in pre-test was 85 ; while the lowest score was 33 and the mean was 58.13. While in the post test of the experimental group the highest score was 93, the lowest score was 62.5 and the mean score was $74.96(\mathrm{~d}=15.666)$.

As compared with the experimental group, the highest score of the control group in the pre-test was 83, while the lowest score was 38 and the mean was 54.8. In the post-test section, the highest score was 88 , while the lowest one was 38. The mean of the post-test in control group was $50.83(\mathrm{~d}=4.7)$. The summary of the effect of ISG on listening comprehension is presented in table 1.

Table 1. The Effect of ISG on Listening Comprehension

\begin{tabular}{llllllc}
\hline \multicolumn{1}{c}{ Group } & $\mathbf{N}$ & Mean & Std.Deviation & $\mathbf{t}_{\text {obs }}$ & $\mathbf{t}_{\text {table }}$ & $\boldsymbol{\alpha}$ \\
\hline Control & 30 & 4.7 & 288.3 & & & \\
Experimental & 30 & 15.666 & 2530.6667 & 6.42 & 2.00 & 0.05
\end{tabular}

The result of the $t$ test analysis, as seen in table 1, reveals that the ISG significantly affects listening comprehension $\left(\mathrm{t}_{\text {obs }}>\mathrm{t}_{\text {table }}=6.42>2.000 ; \alpha=0.05\right)$. It proved that the interaction story game used in the experimental group significantly affected listening comprehension.

Based on the results of this study, it was concluded that ISG itself did not directly facilitate better listening comprehension. Such facilitation was resulted from the ISG's ability to increase the students' cognitive engagement during the process of listening comprehension which causes the students to be more focused and concentrated on comprehending the text. Such ability of ISG was partly from the contribution of motoric involvement. The quality of the program or the software which caused the students to be challenged, to feel more competitive, and to be curious also provides a lot of contribution to the development of cognitive engagement among the students. The suitability of the language or text applied by ISG as the medium of verbal interaction among the players and instructors also played an important role in the development of cognitive engagement. So the effectiveness of ISG in facilitating the students' listening comprehension was dependent on three factors, namely program quality (software), quality of verbal interaction, and hardware quality (the tool). 


\section{Discussion}

This study explored the effect of Interaction Story Game (ISG) on Listening Comprehension. The assumption underlying this study is that better listening comprehension will be achieved if deep cognitive engagement and motoric involvement take place in one's activity. The competition among the players, the battle they want to win, and the problems they want to solve make the players cognitively engaged. They have to concentrate on the instruction given by the instructors in ISG and perform as instructed in order to win the battle, win the competition or solve the problem. There is no direct effect of ISG on listening comprehension. What significantly affects the students' listening comprehension is the program developed in the ISG.

In terms of interactive games, there was one thing that served as the basis of this finding. Shaffer (2005) stated that virtual world in video games was a powerful tool to stimulate students' interest because it provided motions, pictures, voices, graphics, and also made an authentic context for learning. It was to say that the lesson that was going to be learned could also be learned in a real-life-like situation created in the video game. The study of ISG agree with Shaffer's (2005). The program developed in ISG is interesting and challenging which encourages them to give deep concentration on listening to what the speakers instructed to the players. Besides, the students were also involved in their psychomotor engagement as they also concentrate on watching and control their moves of their opponent. Isik (2010) found out the CALL (Computer Assisted Language Learning) significantly affected listening comprehension. Those students taught with CALL perform listening comprehension better than those taught with conventional method. Isik (2010) also found that students' positive attitude toward using CALL in learning English is one factor that causes the CALL to be effective. The positive attitude makes the students feel good in learning with the CALL. Getting instant feedback is another factor. The CALL also enables the students to be more cognitively and metacognitively active and consequently it improves their listening comprehension ability. Hayati (2011) confirmed the results of this study. In her study, she provided three types of treatment to the three groups of samples. The three groups are assigned to watch the same DVD with the title of Wild Weather. The difference among the three groups is that they received different treatments. In the first treatment, she assigned the samples to watch the Wild Weather with English subtitle; in the second treatment, the movie was provided with Persian subtitle. Persian was the native language of all samples. In the last treatment, the group was assigned to watch the movie without subtitle. The results of the study showed that the group provided with the English subtitle did much better in listening comprehension than the group with Persian subtitle, and the Persian subtitle group perform better than the group with no subtitle. This finding indicated that the Persian subtitle group did not need to work hard to understand the utterances in the movie because Persian was their native language. They did not to engage cognitively very much in understanding the movie. However, they may sometimes pay attention to the utterances they hear and match them with the Persian translation. Such cognitive engagement allowed them to comprehend the utterances. This might be the reason why they performed better than the no-subtitle group. The no-subtitle group performed the worst because they did not have any access to understand the utterances in the movie. They did not get any clue to help them understand the movie therefore they cannot get engaged in bettering their listening comprehension through the movie. The English subtitle group performs much better than the Persian subtitle group. The English subtitle group might have learned English and they might be better in reading than in listening. The movie with the English subtitle allowed them to get more cognitively engaged because they could match the subtitle they heard and the English they learned. The result of this study seemed to confirm that cognitive engagement enabled the students to perform better in listening comprehension. Loniza (2018) conducted a research with integrative design in which experimental design was followed by descriptive qualitative design. In the quantitative study, the experimental group was taught by using digital story Storytelling while the control group was taught by using conventional method. The data analysis showed the scores of listening comprehension achieved by the experimental group is much higher than those achieved by the control group. This indicated that the digital storytelling significantly affected listening comprehension. The qualitative data analysis of this study showed that the students in the experimental found the digital storytelling enjoyable because the storytelling was provided with images, video, audio narration, and music. It maybe these factors which caused the students to get more engaged and motivated in listening to the storytelling and therefore their concentration to the audio narration became increased and consequently their listening comprehension was much better.

\section{Conclusion}

The cognitive engagement and motoric involvement that the ISG triggers successfully facilitated the listening comprehension achievement. The development of challenging game program, interesting visualization of the setting and game characters as well as the audio instruction between the machine and players enabled the ISG to trigger the cognitive engagement and motoric involvement. So the effectiveness of the ISG as an instructional media for listening comprehension was not only dependent on how interest the game but also on some other factors, like how challenging the game program was, how well the ISG could make the game players active, and how well the audio instruction could instruct the game players to win the game. 


\section{References}

Andringa, S. N. (2012). Determinant of Success in Native and Non-Native Listening Comprehension: An Individual Difference Approach. Language Learning: A Journal of Research in Language Studies, 49-78. https://doi.org/10.1111/j.1467-9922.2012.00706.x

Arnaldi, M. (2014). Four Factor Psychologies as Executive Function to Increase Interest of Learning. Procedia: Social and Behavioral Sciences, 503-509. https://doi.org/10.1016/j.sbspro.2014.01.1195

Conrad, L. (1989). The Effects of Time-Compressed Speech on listening Comprehension. Studies in Second Language Acquisition, 11, 1-16. https://doi.org/10.1017/S0272263100007804

Coyle, M. (2014). The effects of Using Smartboard and Interactive Games to improve Reading Comprehension of Secondary Students with Moderate Cognitive Disabilities (Unpublished Thesis).

Hayati, A., \& Firooz, M. (2011). The Effect of Film with and without substitles on listening comprehension of EFL learners. British Journal of Educational Technology, 42(1), 181-192. https://doi.org/10.1111/j.1467-8535.2009.01004.x

Isik, C., \& Sumeyra, Y. (2010). E-Learning in Life long Education: A Computational Approach to Determining Listening Comprehension Ability. Education and Information Technologies, 16, 71-88. https://doi.org/10.1007/s10639-009-9117-9

Loniza, A. F., Aslina, S., \& Mazlina, C. M. (2018). The Effectiveness of Digital Storytelling on Language Listening Comprehension of Kindergarten Pupils. The International of Multimedia\&Its Application, 10(6), 131-141. https://doi.org/10.5121/ijma.2018.10611

McLaughlin, M. M. F. (2005). Student Content Engagement as a Construct for the Measurement of Effective Classroom Instruction and Teacher Knowledge. Washington DC: American Institute for Research. https://doi.org/10.1037/e539752012-001

Olstrom, N. C. (2012). Determinants of Success in Narrative and Non-Narrative Listening Comprehension: An Individual Differences Approach. Language Learning: A Journal of Language Studies, 5605-5611.

Rost, M. (2011). Teaching and Researching Listening 2ed. Harlow: Pearson Education Limited.

Sarandi, H. (2010). Content Related Support and Listening Comprehension: Some Limitations. Procedia: Social and Behavioral Sciences, 5605-5611. https://doi.org/10.1016/j.sbspro.2010.03.914

Shaffer, D. S. (2005). Video Games and the Future of Learning. Phi Delta Kappan, $104-111$. https://doi.org/10.1177/003172170508700205

Sourivayongsa, T. R. (2013). Factors Causes Students Low English Language Learning: A Case Study in the National University of Laos. International Journal of English Language Education, 179-192. https://doi.org/10.5296/ijele.v1i1.3100

Underwood, M. (1999). Teaching Listening. London: Longman

Vahdat, S., \& Behbahani, A. R. (2013). The Effect of Video Games on Iranian EFL Learners' Vocabulary Learning. The Reading Matrix, 13(1), 61-71. 